\title{
Educational Management of Foreign Students at the Higher Military School: An Ecosystem Approach
}

\author{
Roza M. Sherayzina 1[ORCID 0000-0002-7358-0689], \\ Marina V. Alexandrova 1[ORCID 0000-0003-1745-4730], \\ Lira Yu. Monakhova ${ }^{2 *[O R C I D ~ 0000-0003-1748-0891], ~}$ \\ Varvara V. Kurdubova 3[ORCID 0000-0003-0129-2722]
}

\author{
${ }^{1}$ Yaroslav-the-Wise Novgorod State University, Veliky Novgorod, Russia \\ ${ }^{2}$ Institute of Education Management of the Russian Academy of Education, Moscow, Russia \\ ${ }^{3}$ The S.M. Budyonny Military Academy of the Signal Corps, Saint Petersburg, Russia \\ lira.monahova@gmail.com
}

\begin{abstract}
The problems associated with the management of the educational process of students in a higher military school from the point of view of the ecosystem approach in pedagogical science and practice have not been previously studied. The ecosystem approach is considered by the authors as a new management paradigm for organizing the educational process, where one of the fundamental ideas is reliance on data from international educational and economic statistics (Education Index, Global Index of Cognitive Skills and Educational Attainment, Global Education Expenditure, Human Development Index). The purpose of the article is to form an idea of the management of an integral ecosystem in which foreign servicemen who study in Russian military educational organizations function. Research objectives were: substantiation of methodological approaches to the management of the educational process of foreign students in Russian military universities, ensuring the implementation of ecosystem methodology, integrated with thesaurus and praxeological approaches; the need to identify the structural components of the ecosystem (deterministic and variable); proof of the validity of the allocation of eco-segments in the integral ecosystem of a military university; determination of diagnostic parameters for the eco-segmentation of the integral ecosystem of a higher military educational institution that manages the process of training foreign military personnel. To solve the set tasks, V.A. Yasvin, adapted by the authors for the examination of eco-segments of a higher military educational institution, as well as the method of cluster analysis of data (K-means algorithm with normalized data) to prove the validity of the hypothesis put forward about the heterogeneity of the integral ecosystem of a military university and the need for its segmentation to improve the efficiency of management decisions. The result of the theoretical part of the research was the proof of the validity of the application of the ecosystem approach to the management of the educational process for foreign students in military educational institutions of Russia; the need for segmentation of an integral ecosystem based on the put forward characteristic parameters (breadth, intensity, awareness, etc.) in order to determine the subject composition of each eco-segment and estimate their total number for each new set of students. The study is focused on improving the quality of management of the educational process by adapting educational programs common for Russian and foreign students and variations of the didactic component of the ecosystem for each of the identified eco-segments.
\end{abstract}

Keywords: foreign military personnel, Russian military university, educational eco-segment, characteristic parameters of the ecosystem

\section{INTRODUCTION}

Traditionally, the organization of the educational process in a higher military school is guided by state educational standards and, at the same time, implements military vocational training regulated by the legislation of the Russian Federation, departmental orders and directives. The inclusion of 
students from foreign countries in the educational process of military universities is one of the directions of state policy in the field of strengthening the country's defense capability and economic cooperation.

An educational organization that implements programs of military-professional education is a closed system, the management of entry and successful functioning in which a foreign student requires special scientific research. Under these conditions, the relevance and timeliness of addressing the problems of managing the educational process of foreign students at a higher military school from the standpoint of the ecosystem approach is beyond doubt.

In the field of pedagogical knowledge, issues related to educational ecosystems have begun to be raised relatively recently. A sufficient number of examples of determinologization can be cited, when the terms used in natural and technical sciences begin to be widely used in the field of pedagogical knowledge. At the same time, it is clear that the semantics of deterministic terms is undergoing changes. This also affected the term "Ecosystem", which came to pedagogy, as you know, from biological science.

It can be argued that the concept of "educational ecosystem" until now has no unambiguous interpretation $[1,2]$.

An analysis of the meanings put by different authors in the interpretation of the term "educational ecosystem" showed that none of them gives a clear idea of the structural, content and procedural components of this concept. There are three contexts that advocates of the ecosystem approach to the organization of the educational process put forward.

The first is slogan-declarative: the educational ecosystem is a new management paradigm for organizing the educational process [3, 4], ecosystems is the direction of the development of the world education system in the modern world [5]. The second one connects the ecological approach to the organization of the educational process exclusively with innovative movements in the field of pedagogical theory and practice $[6,7]$. The third context, within which the educational ecosystem is considered, is associated with the processes of informatization and digitalization of all spheres of human activity [8-10].

The analysis of scientific sources showed that from the standpoint of the ecosystem approach, issues related to the organization of the educational process of foreign students in a higher military school were not considered.

The authors of the article investigate the problem of the formation, development and reflection of educational activities organized for foreign students at a higher military school from the standpoint of the ecosystem approach. At the same time, it is supposed to get answers to the following questions:

- what component composition can be used to represent the ecosystem of organizing the management of the educational process of foreign students in a higher military school

- what meanings should be given to the descriptive definition of the ecosystem approach in the context of managing the military-professional training of foreign students;

- what results will be obtained by diagnostics of individual management components of the ecosystem of the organization of the educational process of foreign students in a higher military school.

The article proposes to build an ecosystem approach to the management of the educational process for foreign students at a higher military school based on the integration of the thesaurus and praxeological paradigms.

The methods of processing the statistical material obtained during the experiment were used as methods of vector modeling and examination of the educational environment by V.A. Yasvin [11] and the method of cluster data analysis (K-means algorithm with normalized data), which show the heterogeneity of the announced ecosystem and the need for its segmentation, and also carried out a comparative analysis of ecosystem parameters for Russian and foreign students.

\section{MATERIALS AND METHODS}

The goal of the study is to identify the structural and content elements of the ecosystem of a military university, in which the training of foreign military personnel is managed. The implementation of this goal presupposes the solution of the following tasks:

- to investigate the management structure of the ecosystem of a military university and to identify "deterministic" - strictly regulated components, and "variable" - components that can be changed by teachers;

- based on the component analysis of the 
organization of the educational process of foreign students at a military higher school, formulate the author's semantic understanding of the ecosystem in which a citizen of a foreign state ends up, in which they learn and socialize;

- to experimentally test the influence of individual structural components of the ecosystem on the quality of the organization of the educational process of foreign students based on self- and expert assessments.

The authors put forward thesaurus and praxeological approaches as a methodological basis for studying the problems of managing the educational process of foreign students at a higher military school.

The thesaurus approach is interpreted as a methodology focused on the development of systemically organized socially and professionally significant knowledge [12]. In this case, knowledge is identified as a thesaurus, while it is clear that we are not talking about a thesaurus as a form of a dictionary, and knowledge is not identified exclusively with the mastery of the meanings of a certain set of terms. Within the framework of the thesaurus approach, one or another scientific subject area is a syntactically determined open information basis, semantically structured in accordance with the currently existing specific relationships for it, which is identified as a scientific thesaurus [13]. And since the organization of the educational process of foreign students is subject-oriented, the problem arises of selecting a logically closed subset of the corresponding scientific thesaurus, intended for assimilation by students with the aim of their successful orientation and functioning in the subject area under consideration [13], which we call a subject thesaurus - a thesaurus intended for assimilation by a person within the framework of a certain academic discipline. Such a subject thesaurus is an element of the ecosystem of a military university, which is located at the intersection of "deterministic" and "variable" regulations that determine the organization of the educational process in a higher military school.

As the second methodological basis, underlying the analysis of problems associated with the ecosystem, in which a foreign student ends up and in which they live for several years of their life, we put forward a praxeological approach that determines the theory and practice of effective management of professional and personally significant human activities [14].
This approach in the best way ensures the implementation of the modern educational paradigm, focused on mastering a set of methods of action, leading to the expected result of life activity. Reliance on a praxeological approach in teaching foreign servicemen in Russian universities allows us to re-evaluate the effectiveness of educational activities and their effectiveness, timely identify educational deficiencies and predict success, if necessary, correct activities, determine the strategy and tactics of social adaptation and professional development.

The ecosystem approach in the context of the research carried out made it possible to eliminate the contradiction between the multidimensional plan of subject thesauri and the linear plan of its translation by means of the language code. Nevertheless, the authors associate its implementation with the constraints represented by the tuple: $(\mathrm{t}, \mathrm{g}, \mathrm{d})$, where $t$ is the content of the subject thesaurus assigned by the learner; $(g, d) \in G^{\times} D$, where $G$ is the set of learning technologies, D is the set of factors that determine the readiness and motivation of the student to perceive the subject thesaurus. This contradiction can be eliminated by relying on a praxeological approach focused on achieving maximum results with minimum resource costs.

To collect statistical material from the experimental part of the study, we used such methods as questioning and testing participants in the educational process (students, teachers, organizers of the learning process), as well as observing the dynamics of the effectiveness of training.

The processing of experimental data to confirm the hypothesis about the heterogeneity of the ecosystem of the higher military school, in which foreign students operate, was carried out using the method of vector modeling and examination of the educational environment [11]. Using the method of cluster data analysis, it was proved that the integral ecosystem of a military university is represented as a set of eco-segments, which made it possible to carry out their typology and calculate the values of the characteristic system parameters of each ecosegment.

\section{RESULTS}

The idea of finding a universal methodological basis for describing the activities of a person functioning in the field of education is not new. By now, more than a dozen methodological approaches 
in pedagogy can be named, which reflect certain aspects of "subject-subject" relations that arise in the processes of teaching, learning and upbringing.

The authors of the article propose an ecosystem approach as a universal methodological basis for describing the management of the educational process of foreign students at a higher military school.

In a broad sense, the ecosystem approach allows you to describe a single set of controlled environments for the functioning of an individual. Higher military school is an autonomous closed ecosystem in which the organic collaboration contains mechanistic components (regulations, instructions, schedules) and organic (values, meanings, multiculturalism).

The ecosystem approach, which is proposed as a methodological basis for organizing the training of foreigners in military educational institutions, involves the creation and development of a set of favorable supportive environments that provide educational resources and streamlined, harmonious relations between participants in multicultural communities.

Considering the ecosystem of a military university, we note that the educational activities of students in them are combined with military professional training, citizens of the countries of the near and far abroad are trained. For both the educational process is organized in Russian. Students from far abroad, before taking the main course, additionally undergo a preparatory course for a year in order to study the Russian language and repeat the basic sections of mathematics and physics necessary for further professional education. Thus, the ecosystem of a military university acquires the features of cross-cultural social stratification.

Under these conditions, students from foreign countries have differences that exist outside the individual (social norms, roles, values) and differences determined by the individuality of each of them (perceptions, motivations, formed patterns of social behavior and subjective culture). There is an obvious crossing of the boundaries of different cultures within the framework of one educational organization.

The study of the structure of the ecosystem of a military higher educational institution made it possible to identify the following components that regulate managerial impact: semantic, subjective and didactic, which can be interpreted as environments, the integration of which forms an integral ecosystem [15].

The semantic and subjective components are deterministic environments, they do not allow for the possibility of correction by the participants of the educational process, while the didactic environment is considered as variable, designed by the teaching staff with an orientation to the requirements of the Federal State Educational Standards (FSES) and the readiness of students to master the educational program.

Let us consider the characteristics of each component (environment) of the ecosystem of the organization of the educational process of foreign students in a higher military school.

The semantic environment is determined by the type, type and category of the educational organization and corresponds to the level and focus of the educational programs implemented by it. The peculiarities of management within the framework of the semantic environment of the ecosystem under consideration are characterized by isolation; the army way of life of students; a special educational and material base focused on training military professional disciplines. The social norms adopted in the military educational organization are generally recognized rules, patterns of behavior and activity. Foreign students must comply with the requirements of military discipline stipulated by the law of the Russian Federation and the representative state; and also observe the official hierarchy adopted in the military organization.

It is clear that social norms are largely determined by cultural and spiritual traditions adopted in a particular state, therefore, as a third characteristic of the semantic environment, we put forward the peculiarity of communication between participants in the educational process. On the one hand, communication is carried out in a crosscultural relationship between representatives of different states, on the other hand, communication is limited due to the closed nature of the military organization. The basis of intercultural communication is the Russian language, which acts as a conceptual and terminological apparatus of military-professional communication.

The subjective environment as a component of the ecosystem of the higher military school for foreign students encompasses students, the teaching staff, and the service for ensuring the educational process. 
The contingent of students is quite diverse both in terms of age and level of training.

A feature of the teaching staff is the division of the teaching staff into military personnel and civilian personnel, while the prevalence of the male contingent is observed.

The service for the provision of the educational process, in accordance with official duties, is engaged in the organization of educational and educational activities. These are the heads of courses, divisions, employees of the training department, commanders of training and national groups.

Let's move on to the didactic variable component of the ecosystem under consideration. The fulfillment of the requirements of the Federal State Educational Standards is carried out here, taking into account the multicultural nature of building the educational process in a foreign language for students (Russian-speaking) environment of a military university.

The didactic environment is characterized by the peculiarities of the selection of the content of education in the construction of the educational program, the specificity of teaching methods and technologies. The didactic component of the ecosystem of a military educational organization is designed with an orientation towards different levels of readiness of foreign students to master the proposed educational programs.

Thus, by the ecological system of organizing the educational process of foreign students in a higher military school, we understand the integration of the educational environments described above: semantic, subjective and didactic.

An experimental study of the ecosystem of a military educational organization for foreign students showed that it (the ecosystem) is not homogeneous. The results of the experiment allowed us to conclude that the ecosystem of a military university can be represented as a set of ecosegments, each of which is described by the listed structural components (semantic, subjective, didactic) and can be further segmented (detailed).

To identify the nature (degree) of ecosystem heterogeneity, the following methods were applied:

- methods of vector modeling and examination of the educational environment [11], adapted by the authors for diagnostics of the ecosystem of a higher military educational institution;
- the method of cluster analysis of data (Kmeans algorithm with normalized data).

The statistical material for the research was the results of a questionnaire survey of the subjects of the ecosystem - students, teachers, organizers of educational activities, carried out in accordance with the methodology of V.A. Yasvin [11]. The experiment, conducted in 2019-2021 at The S.M. Budyonny Military Academy of the Signal Corps, involved twelve teachers of the departments of the natural science cycle and more than two hundred second-year cadets.

It was suggested that it is possible to correctly describe the ecosystem of a military university through a set of eco-segments. Two divisions of the educational organization were chosen as ecosegments - the main one (for training Russian cadets) and the special one (for foreign students). The purpose of this stage of the study was to clarify the question of the identity of the selected segments (based on assignment to one type).

For the examination of these eco-segments, a diagnostic procedure was carried out, as a result of which typologization was carried out and the values of the characteristic system parameters of each segment were calculated. Analysis of the results obtained showed:

- "personality vectors" of the student of the main and special faculties allow for attributing the eco-segments of these faculties to different types: dogmatic (main division), creative or career (special division); the same is evidenced by the different values of the characteristic system parameters for the studied eco-segments (Figure 1);

- the estimates of the spread of the calculated values relative to the mean values (standard deviations) for the eco-segment of the special division significantly exceed the corresponding estimates for the main division, which reveals the need for further downscaling (detailing) of the eco-segment of the special division.

Thus, it was revealed that the eco-segments of the main and special divisions belong to different types, which allows us to conclude that the ecosystem of a military university as a whole is heterogeneous.

Figure 1 shows the values of the characteristic parameters for the eco-segments of the main and special faculties of a military university, calculated 
using the methodology of vector modeling by V.A. Yasvin, adapted by the authors.

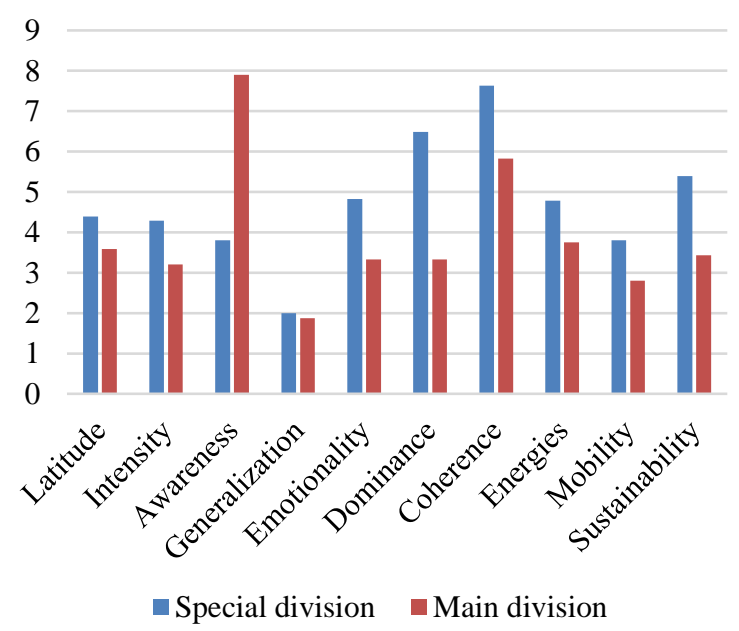

Figure 1. Values of diagnostic parameters for ecosegments of a higher military educational institution Source: Compiled by the authors

At the final stage of the experimental study of the ecosystem of a military educational organization, the ecosystem was divided into clusters-ecosegments. The division was carried out using cluster analysis; the subjects (students) of the ecosystem of a military university were subject to distribution. Intensity (characterization of the degree of filling of the educational environment with conditions and opportunities for learning), generalization (characterization of coordination of the activities of all subjects of the ecosystem), mobility (mobility of goals and content, methods and means of teaching) were chosen as the analyzed characteristics of the subject.

It should be noted that the peculiarities of the organization of the educational process in a military higher educational institution make it possible to consider some of the parameters as conditionally deterministic, and some as variable. We found that such parameters as: intensity, generality, mobility, considered as internal characteristics of the ecosystem, can be corrected due to a change in the content of structural components, the remaining parameters, due to the specifics of the organization of the educational process, will be considered practically unchangeable.

The procedure for clustering the subjects of the ecosystem of a military university (the K-means algorithm with normalized data implemented using the Python language), at the first step, made it possible to distinguish two clusters: a cluster corresponding to subjects-Russian students, and a cluster corresponding to subjects-foreign students, which confirmed the result of heterogeneity of the ecosystem as a whole. At the second step of clustering, three statistically significant clusters were identified in the statistical data for foreign students (Figure 2), and no significant clusters were found in the statistical data for Russian students.

Figure 2 shows the results of cluster analysis for the classification of subjects-foreign students using "intensity-generalization" parameters. The analysis of the subjects included in the selected clusters allows us to make the assumption that the cluster unites subjects with a similar level of readiness for learning. Thus, the first cluster brings together students from five African states and two states of Southeast Asia, which have a low level of readiness to master educational programs, in the second representatives of three African countries with the necessary level of readiness, in the third - students from two states of South-East Asia. East and East Asia (high availability) [16.]

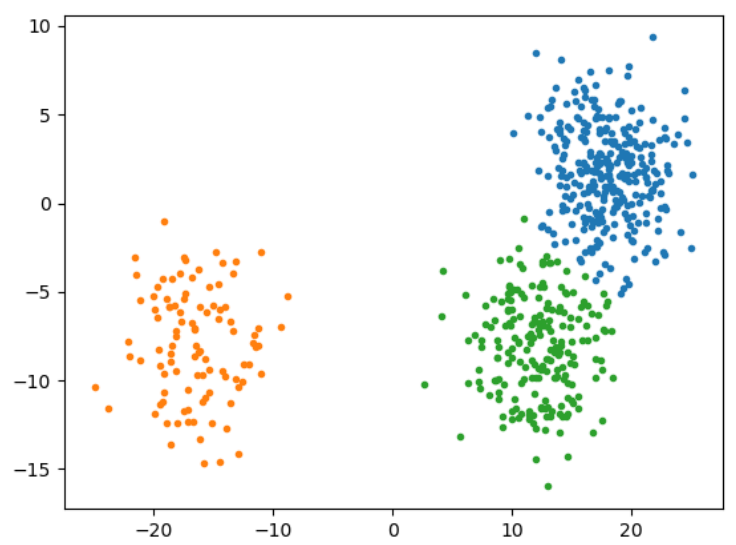

Figure 2. Results of cluster analysis of the ecosystem for foreign students on the basis of "intensity-generalization" Source: Compiled by the authors

The results of the experimental study allow us to conclude that the ecosystem of the organization of the educational process for foreign students of a military university does not have the property of homogeneity and is represented by a set of a finite number of eco-segments. Designing management influences on the educational process in each ecosegment requires separate didactic support, which indicates the influence of the didactic structural component of the ecosystem on the quality of the organization of the educational process.

The authors assume that the clustering of an ecosystem into eco-segments is largely due to the multi-level readiness of students to master the 
proposed educational programs, caused, in particular, by the peculiarities of the educational management of states. The study compares national educational systems by means of analyzing data from international educational and economic statistics, including: ratings of countries in the world by education level (according to the United Nations); ratings of countries in the world by the level of spending on education (according to the World Bank); data from the International Program of the Organization for Economic Cooperation and Development for assessing the competencies of the adult population and the International Program of the Organization for Economic Cooperation and Development for assessing the quality of mathematics and science education. To compare national educational management strategies, the following indicators have been proposed: Education Index, Global Index of Cognitive Skills and Educational Attainment, Global Education Expenditure, Human Development Index [16]. The authors are also interested in the study of the dynamics of the Index of National Expenditures on Education, as one of the most important indicators of social development, which characterizes the attitude of the state to the education of citizens.

\section{DISCUSSION}

A significant number of studies have been devoted to the problems of teaching in a foreignlanguage cross-cultural environment of higher education. Basically, they relate to aspects of teaching Russian as a foreign language, the development of a didactic basis for teaching foreign students, issues of psychological and pedagogical adaptation of students. Some aspects of the educational process in a higher military school are devoted to studies related to the formation of readiness for learning, adaptation to the environment of a military university, informatization of the educational environment. However, as the analysis of the studies shows, a holistic study of the managerial aspect of organizing the educational process for foreign students of a military university has not been carried out.

The authors of the article propose an ecosystem approach as a universal methodological basis for describing the organization and management of the educational process of foreign students at a higher military school. The study of the structure of the ecosystem of a military university determined its components: semantic, subjective and didactic. The results of the experimental study made it possible to conclude that the ecosystem of the organization of the educational process for foreign students of a military university does not have the property of homogeneity and is representable by a set of a finite number of eco-segments.

\section{CONCLUSION}

The article presents the results of a study of the problems of managing the educational process of foreign students in a higher military school. For the first time, the problems of teaching in a foreignlanguage cross-cultural environment of higher education are presented from the standpoint of the ecosystem approach. The component composition of the ecosystem of the organization of the educational process of foreign students at the higher military school is revealed and substantively described, deterministic and variable components are highlighted, the term "eco-segment" of the ecosystem is proposed. It has been substantiated that the thesaurus and praxeological approaches are the optimal methodological basis for studying the problems of managing the educational process of foreign students in a higher military school. It has been experimentally proven that the ecosystem of the organization of the educational process for foreign students of a military university is represented by a set of a finite number of ecosegments, the design of the educational process for each requires separate didactic support, which indicates the influence of the didactic structural component of the ecosystem on the quality of the organization of the educational process.

Dividing the ecosystem into eco-segments allows managers of the educational process at a higher military educational institution to assess the expected number of eco-segments and form their composition.

An analysis of the values of the characteristic parameters obtained for each eco-segment (latitude, intensity, awareness, etc.) showed that improving the quality of the organization of the educational process for foreign students is possible by varying the didactic structural component of the ecosystem, including approaches to the design of training programs, features of the selection of content training, the specifics of teaching methods and technologies. The next stage in the study of the organization of the educational process of foreign students in a higher military school is the distribution of foreign students according to the levels of readiness for training, which is supposed to be carried out on the basis of the author's methodology presented in [17]. 


\section{AUTHORS' CONTRIBUTIONS}

Research concept - Roza M. Sherayzina. Research design - Marina V. Alexandrova. Collection and statistical processing of material Varvara V. Kurdubova. Writing the theoretical part of the text - Lira Yu. Monakhova. Writing a practice-oriented part of the text - Varvara V. Kurdubova. Editing - Lira Yu. Monakhova.

\section{REFERENCES}

[1] M. Bogers, J. Sims, J. West, "What Is an Ecosystem? Incorporating 25 Years of Ecosystem Research", Academy of Management Annual Meeting Proceedings, 2019, vol. 1, p. 11080. DOI: 10.5465/AMBPP.2019.11080abstract

[2] R. Adner, "Ecosystem as structure: an actionable construct for strategy", Journal of Management, 2017, vol. 43(1), pp. 39-58.

[3] L.V. Kuklina, S.Ya. Kuklin, "Theoretical background for the ecosystem research approach to the management of educational activities", Modern Pedagogical Education, 2021, vol. 8, pp. 27-33. (In Russ.).

[4] J. Barokas, I. Barth, "Multi-stakeholder ecosystems in rapidly changing educational environments", in Proceedings of the IEEE Global Engineering Education Conference, 2018, pp. 1934-1938. DOI: 10.1109/EDUCON.2018.8363472

[5] S.N. Makhnovets, O.A. Popova, "A new ecosystem of education as a backbone vector of quality of life", Vestnik Tver State University. Series: Pedagogy and Psychology, 2017, vol. 4, p.141-149. (In Russ.).

[6] R. Kumari, K.-S. Kwon, B.-H. Lee, K. Choi, "Co-creation for social innovation in the ecosystem context: The role of higher educational institutions", Sustainability, 2020, vol. 12(1), p. 307. DOI: 10.3390/su12010307

[7] M. Cervantes, "Higher education institutions in the knowledge triangle", Foresight and STI Governance, 2017, vol. 11(2), pp. 27-42. DOI: 10.17323/2500-2597.2017.2.27.42

[8] M.A. de Souza Rodrigues, P. Chimenti, A.R.R. Nogueira, "An exploration of eLearning adoption in the educational ecosystem", Education and Information Technologies, 2021, vol. 26, pp. 585-615. DOI: 10.1007/s10639020-10276-3

[9] S. Sergis, D.G. Sampson, M. Giannakos, "Enhancing Student Digital Skills: Adopting an Ecosystemic School Analytics Approach", in Proceedings of the 17th International Conference on Advanced Learning Technologies, 2017, p. 21-25. DOI: 10.1109/ICALT.2017.87

[10] V. Panthalookaran, "Development of an educational ecosystem that supports engineering research", in Proceedings of the IEEE Global Engineering Education Conference, 2019, pp. 71-78. DOI: 10.1109/EDUCON.2019.8725055

[11]V.A. Yasvin, "Instrumental expertise in the process of pedagogical design of the school environment" [Instrumentalnaya ekspertiza v processe pedagogicheskogo proektirovaniya shkolnoj sredy]: Abstract of the Doctor in Pedagogical Sciences thesis, Moscow, 2020. (In Russ.).

[12] V.A. Lukov, "Thesaurus Approach", Knowledge. Understanding. Skill, 2018, vol. 3, pp. 247-252. (In Russ.). DOI: 10.17805/zpu.2018.3.23

[13]L.Yu. Monakhova, "Informatization of mathematical education in the system of professional training of military specialists" [Informatizaciya matematicheskogo obrazovaniya $\mathrm{v}$ sisteme professional'noj podgotovki voennyh specialistov]: Abstract of the Doctor in Pedagogical Sciences thesis, Veliky Novgorod, 2005. (In Russ.).

[14]L.Y. Monakhova, V.S. Fedotova, "Praxiocentralism in the professional standard of the teacher", Education and Science Journal, 2017, vol. 19(4), pp. 9-38. (In Russ.). DOI: 10.17853/1994-5639-2017-4-9-38

[15] V.V. Kurdubova, "Structural Components of the Educational Environment for Foreign Students at a Military University", The Emissia. Offline Letters, 2020, vol. 11, p. 2888. (In Russ.).

[16] "Human Development Reportsh 2021/2022", United Nations Development Programme, 2021. Retrieved from http://hdr.undp.org/en

[17] L.Y. Monakhova, V.V. Tanyukhina, "Research of levels of foreign cadets' readiness to study at military academies", Man and Education, 2012, vol. 1(30), pp. 112-116. (In Russ.). 